\title{
Mitigation, Specific Performance, AND THE PROPERTY DEVELOPER: SOUTHCOTT ESTATES INC. V. TORONTO CATHOLIC DISTRICT SCHOOL BOARD
}

\author{
JEFF BERRYMAN*
}

\section{INTRODUCTION}

Ever since the decision of the Supreme Court of Canada in Semelhago v. Paramadevan, which changed the law on the availability of specific performance for breach of contract, property developers have found the door to that remedy effectively closed. ${ }^{1}$ The recent decision of the Supreme Court in Southcott Estates Inc. v. Toronto Catholic District School Board confirms that trajectory despite the valiant attempts by some developers to bring their cases within the rubric of the Semelhago decision. ${ }^{2}$ However, Southcott is not so much a case about specific performance as it is a case about the obligation to mitigate and how a defendant can prove that a plaintiff has failed to make reasonable efforts to mitigate. It is also a case where the plaintiff sought to plead that it was a "volume buyer," the obverse of a "volume seller," and whether this fact meant that it did not have to take the profit from a subsequent purchase into account as an act of mitigation.

\section{FACTS AND FINDINGS}

In Southcott, the plaintiff developer, a single purpose company, was a subsidiary of Ballantry Homes, a holding entity for a number of other single purpose companies that developed property in the wider metropolitan Toronto area. The plaintiff wished to purchase vacant land from the defendant Board, land that was surplus to the Board's needs, but which was first required to be severed through an appropriate planning application. The parties negotiated an agreement for sale and purchase which was conditional upon the Board obtaining the appropriate planning severance and which also gave the plaintiff a further thirty days in which to exercise due diligence to ensure that it could successfully develop the land into residential building lots. The Board was dilatory in making attempts to secure the planning consent. It was reluctant to go through this process while there was a possibility that the purchaser would itself be unable to secure consent to a viable residential development. In spite of a number of extensions of time, the Board never secured the planning severance and the plaintiff commenced suit for breach of contract claiming that the Board failed to use best efforts to secure the planning approval. Most of the trial judgment is devoted to determining whether the Board had in fact breached its contractual obligation to use best efforts to secure planning consent, and it is clear that this is where most of the parties had spent their time in the trial. The trial judge found for the plaintiff and held that the Board was deficient in numerous respects in failing to secure the planning severance. This established both breach of contract and causation, the Board's breach giving rise to a consequential loss of profits on the potential development of the subject land.

Professor, Faculty of Law, University of Windsor, and Faculty of Law, University of Auckland (fractional chair). 
At trial, the plaintiff requested specific performance and sought to take on the evidential burden now imposed on plaintiffs as a result of the decision in Semelhago that this property was unique and that the plaintiff held a fair, real, and substantial justification for its claim. Judge Spiegel, the trial judge, quickly found against the plaintiff on this point, poignantly noting that:

Indeed, the plaintiff's counsel candidly admitted that he was unable to refer the court to any case decided after Semelhago in which specific performance had been granted in respect of the purchase of property for investment. ${ }^{3}$

Unable to secure specific performance, the plaintiff asked for damages, not in lieu of specific performance but for breach of contract. The parties agreed that the value of the land had not increased between the time the contract had been formed, the date of breach, or the date of trial, the relevant period being affected by the global economic crisis during that period. The plaintiff claimed for consequential losses, those that flowed from the loss of profits envisaged from a successful residential development had the contract been performed. Because the eventual development was dependent upon securing planning consent, a matter which ultimately lay in the hands of a third party, the municipality, the assessment of damages engaged the loss of a chance analysis relying upon the well-trod principles applied in Folland v. Reardon. ${ }^{4}$ The loss of a chance was placed at 60 percent of the expected profits. However, the defendant also challenged the assessment of damages claiming that the plaintiff had failed to avail itself of an opportunity to mitigate its losses. In particular, the defendant claimed that, following its breach, the plaintiff could have purchased similar development property and thus lessened the lost profits incurred. With the evidential burden being placed on the defendant to prove that the plaintiff did not avail itself of an opportunity to mitigate, the defendant adduced evidence that during the relevant period other companies in the Ballantry Group did purchase development property. In addition, the defendant provided evidence that some 81 parcels of land were available for development and that 49 properties had been subdivided during the relevant period.

Judge Spiegel did not accept the defendant's submission on mitigation. The fact that other Ballantry companies had purchased land was characterized as "collateral” activity. Ballantry was always in the market for land; it had the financial resources to make those purchases regardless of its commitment to the transaction with the defendant, and thus, those subsequent dealings did not arise out of the consequences of the breach and were not steps made in mitigation. Judge Spiegel rejected the evidence of the availability of other properties on the basis that the evidence did not actually demonstrate that the properties were available to the plaintiff for sale or that they were capable of profitable development, only that they had been sold during the relevant period. The plaintiff was awarded $\$ 1,935,500$ in damages (60 percent of $\$ 3,225,827$ ).

The defendant appealed claiming: (1) the trial judge had erred in finding the Board's breach of duty was the proximate cause of the failure to secure severance consent; and (2) 
the trial judge had failed to apply the doctrine of mitigation appropriately. ${ }^{5}$ On the first ground of appeal, the Court of Appeal affirmed the trial judge. On the second ground, the Court of Appeal found the trial judge had erred on the assessment of damages in that he failed to take proper account of the evidence concerning mitigation. The Court of Appeal accepted that the defendant's evidence on the availability of other suitable vacant land sites did discharge the onus on the defendant to demonstrate that the plaintiff failed to take reasonable steps in mitigation. To require more of the defendant, as the trial judge had insisted, was to place too high a burden on the defendant. In fact, the Court of Appeal held that the simple assertion by the plaintiff during testimony that it had no intention of mitigating loss, was sufficient to meet the onus on the defendant and to shift the evidentiary onus to the plaintiff to demonstrate that, even if it had taken steps in mitigation, it could not have done so. In addition, the fact that other Ballantry companies had made purchases proved that there was suitable development land available. The Court of Appeal awarded nominal damages of one dollar.

The appeal to the Supreme Court of Canada was on the sole issue of mitigation, and, in particular, what obligation lay on a single purpose company to mitigate, the relationship between mitigation and a claim for specific performance, and whether there was evidence of comparable properties available for mitigation. The Supreme Court, by a majority, affirmed the Court of Appeal's decision.

With respect to the obligation of a single purpose company to mitigate, Justice Karakatsanis, writing for the majority, quickly dismissed Southcott's argument that because it was dependent upon funds to complete the deal flowing from its parent company, Ballantry, all that could be expected of it was to litigate expeditiously in bringing an action for specific performance. Of course, a claim for specific performance meant that Southcott had access to the resources to complete the sale, which, because of the breach, could now be applied to mitigation. In addition, factually, Southcott did not argue that it was impecunious nor lacked access to capital or the ability to borrow at favourable rates. Finally, to distinguish single purpose companies from an obligation to mitigate would unfairly advantage this corporate structure and possibly impose higher damages on defendants who dealt with them. Southcott was also caught on its own petard. It argued that properties purchased by other Ballantry companies had to be treated as collateral because Ballantry was always in the market for land and thus it held no obligation to mitigate. Justice Karakatsanis responded, starting that Southcott cannot claim the benefits of maintaining a separate legal identity with respect to a claim for specific performance, but at the same time claim the benefits of Ballantry's corporate structure in answer to why other comparable properties could not be purchased in mitigation. The sole question was whether the reasonableness of Southcott's actions following breach had been sufficient to satisfy the obligation to mitigate.

With respect to the relationship between specific performance and the obligation to mitigate, the majority reiterated the Court's position previously established in Asamera Oil Corp. v. Seal Oil \& General Corp. ${ }^{6}$ and Semelhago. ${ }^{7}$ Where a plaintiff has a "fair, real, and 
substantial justification”8 for his claim to specific performance then he is acting reasonably, in satisfaction of the obligation to act reasonably to mitigate loss, by not purchasing other property upon the defendant's breach. Thus, everything hung on the plaintiff's claim to demonstrate a fair, real, and substantial justification for specific performance. As a purchaser of property for investment purposes, Southcott could not make such a claim unless it could show that money was not a complete remedy because the land had a peculiar and special value to it. This, it could not prove. As the majority concluded, Southcott "was engaged in a commercial transaction for the purpose of making a profit. The property's particular qualities were only of value due to their ability to further profitability."99

With respect to the evidentiary issue of what the defendant had to prove, the majority reiterated that the onus of proving a failure to mitigate lies on the defendant and is satisfied only upon proof that the plaintiff "failed to make reasonable efforts to mitigate and that mitigation was possible."10 This approach rejected the Court of Appeal's analysis of Southcott's admission that it had no intention of ever mitigating had the effect of shifting the evidentiary onus on to Southcott to prove that even if it had taken steps to mitigate there were no comparable properties available. Rather, the onus always stayed with the defendant, but the trial judge had made an error "in principle in failing to consider relevant evidence" — an error which "skewed his factual analysis on the issue of mitigation." ${ }^{11}$ Combined, these errors constituted a "palpable and overriding error” justifying appellate court intervention.

Turning to the specific evidence before the Court, the majority concluded that the trial judge should have drawn a reasonable inference from the Board's evidence concerning the sale of 81 properties of raw land and the 49 properties actually developed over the relevant time that suitable investment properties were available to Southcott. Similarly, a reasonable inference of profitability flowing from these developments could be drawn based on the fact that other experienced developers had completed the developments. Finally, the majority held that the trial judge had made an error in not accepting the evidence of other purchases made by Ballantry group of companies, of which there were seven developments, as evidence of “"available’ comparable mitigation opportunities.”12

Chief Justice McLachlin dissented in Southcott. She defined the onus upon the defendant to show a failure to mitigate in slightly stronger language, opining that the defendant had to prove the following: "(1) that opportunities to mitigate the loss were available to the plaintiff; and (2) that the plaintiff unreasonably failed to pursue these opportunities."13 The Board's evidence was deficient to meet this test in that its expert witness did not give evidence that any of the properties which had been sold and developed were actually available for sale to the plaintiff, and that the proffered comparable properties were not actually that factually comparable in terms of size, location, or profitability. The Chief Justice also accepted that other purchases by Ballantry companies should be treated as collateral and that Ballantry had the financial capacity to purchase as many good properties as it could find. In addition, none

Asamera, supra note 6 at 668.

Supra note 2 at para 41.

Ibid at paras 24, 45.

Ibid at para 48 .

Ibid at para 55.

Ibid at para 73. 
of the properties purchased by other Ballantry companies were factually comparable, nor was evidence provided that they had been offered to Southcott for purchase. If they had been offered to Southcott, that would have put Southcott in competition with other Ballantry companies and added an element of speculation on whether it would have been successful in acquiring a substitute property.

Contrary to the majority, the Chief Justice accepted that the plaintiff was acting reasonably in pursuing specific performance. Because the actual property did have physically unique characteristics, which were demonstrated by accepting the evidence of lack of other comparable properties, Southcott had a "fair, real, and substantial justification" for specific performance. The fact that the remedy was ultimately denied on discretionary grounds did not change the characterization of Southcott's conduct as being anything other than reasonable. Where the pursuit of specific performance was reasonable, the plaintiff did not have to "effectively concede defeat and buy a substitute property." ${ }^{14}$ Finally, the Chief Justice also accepted that Southcott lacked the financial resources to mitigate because it was dependent solely upon Ballantry for funds and had no assets other than the deposit paid to the Board from funds advance to it by Ballantry. Whether it could have obtained other financing remained speculative.

\section{COMMENTARY}

\section{A. Specific Performance}

The traditional approach to the availability of specific performance, which is still followed in the United Kingdom, was to treat all land as being unique and thus specific performance was treated as a presumptive remedy in sales of real estate. ${ }^{15}$ Canadian law changed with the obiter dicta comments of Justice Sopinka in Semelhago. ${ }^{16}$ Justice Sopinka's comments linked two issues central to an understanding of the availability of specific performance. He said:

\footnotetext{
It is no longer appropriate, therefore, to maintain a distinction in the approach to specific performance as between realty and personalty. It cannot be assumed that damages for breach of contract for the purchase and sale of real estate will be an inadequate remedy in all cases. ${ }^{17}$
}

And later in the same passage:

Specific performance should, therefore, not be granted as a matter of course absent evidence that the property is unique to the extent that its substitute would not be readily available. ${ }^{18}$

The focus of the first comment is upon the inadequacy of damages as an appropriate remedy. The focus of the second comment is upon the attributes of uniqueness of the property. The traditional approach presumes that the value of a property with unique

\footnotetext{
Ibid at para 93.

See Jeffrey Berryman, The Law of Equitable Remedies, 2d ed (Toronto: Irwin Law, 2013) ch 10; John McGhee, Snell's Equity, 32d ed (London: Sweet \& Maxwell, 2010) at para 17-008. Supra note 1.

Ibid at 428.

Ibid at 429 .
} 
attributes is difficult to quantify and thus damages is an inadequate remedy therefore justifying specific performance. In effect, this is the approach the Chief Justice would impose upon Canadian law. Because the Board could not demonstrate that any of the other properties that had been purchased and developed had comparable qualities, such as being available for "single-family residential development within the City of Toronto,"19 damages would not prove to be an adequate remedy and Southcott would have a "fair, real, and substantial justification” to pursue specific performance. While Justice Sopinka may have intended Canadian law to develop in this way post obiter dicta comments, it is not the way Canadian courts have subsequently interpreted his comments.

The weight of subsequent court decisions have focused upon the issue of the inadequacy of damages. For the property developer and investor, this means that it is extremely difficult to justify actually gaining a specific performance decree. When Judge Spiegel made the observation that counsel for Southcott were unable to point to any cases post Semelhago in which a purchaser of property for investment had been granted specific performance, he was merely stating the obvious. ${ }^{20}$ Property developers and investors, by the nature of their business, have commodified the land they seek to purchase into a profit-centred activity. In 365733 Alberta Ltd. v. Tiberio ${ }^{21}$ the Alberta Court of Appeal accurately captured Canadian law when it asserted that

where uniqueness is in the context of a development property and any unique characteristics would be reflected in the sale price or the profits from the investment, damages are capable of calculation and therefore, there is no interest in land and no remedy of specific performance. ${ }^{22}$

This approach is echoed in the majority’s judgment in Southcott quoted earlier. ${ }^{23}$

Prior to Southcott, property developers had, with some ingenuity, attempted to bring their claims for specific performance within the Semelhago rubric. Thus, a property developer argued that the fact that its contemplated development would span a long period of time made the quantification of damages problematic justifying specific performance. ${ }^{24}$ Similarly, where a property developer was intending to purchase a hotel and convert it into condominiums, it argued that profits were speculative because at the time of the purchase it was unknown what conditions would be placed on the required planning consent to convert the hotel to condominiums or what number of units would be approved. ${ }^{25} \mathrm{~A}$ property developer has also argued that specific performance is necessary of a large tract of land in order to maintain its competitive market position and reputation as a property developer. ${ }^{26}$

\footnotetext{
Southcott SCC, supra note 2 at para 95.

Southcott Ont Sup Ct, supra note 3 at para 125.

2008 ABCA 341, 440 AR 177.

Ibid at para 10 .

Supra note 2 at para 41.

See Neighbourhoods of Cornell Inc v 1440106 Ontario Ltd (2003), 11 RPR (4th) 294 (Ont Sup Ct) where a property developer argued that, because it exclusively developed large tracts of land, it was entitled to specific performance of a contract for the purchase of the last remaining large tract of serviceable undeveloped land in Markham, Ontario. Specific performance was refused.

25 Carttera Management Inc v Palm Holdings Canada Inc (2011), 9 RPR (5th) 155 (Ont Sup Ct) application for certificate of pending litigation granted.

410675 Alberta Ltd v Trail South Developments Inc, 2011 ABCA 274, 293 AR 181, leave to appeal to SCC refused, 35192 (27 June 2013). The argument was made but was not supported on the evidence.
} 
Southcott could not bring itself within any of these approaches, and, as the trial judge found, the parties had agreed on how the damages were to be quantified. ${ }^{27}$

Post Southcott, it will be increasingly difficult for a property developer or investor to ever actually gain specific performance. The only exception alluded to by the majority is where the damages are "too speculative or uncertain." ${ }^{28}$ However, unique physical attributes will invariably be factored into the profitability of the venture, and damages will thus prove adequate.

\section{B. Single Purpose Company AND \\ LACK OF FINANCIAL RESOURCES TO MITIGATE}

The majority in Southcott rejected the suggestion that, as a single purpose company, Southcott could rely on its lack of financial resources to undertake mitigation as an additional ground to support specific performance. The Chief Justice, however, accepted this argument.

The notion that a plaintiff's impecuniosity could impact upon its obligation to mitigate, which could then support a claim that it had a fair, real, and substantial justification for specific performance, was indirectly alluded to in Asamera. That case involved a breach of contract to return shares that had been loaned to the defendant to enable it to trade on the stock market. The plaintiff could not delay its obligation to mitigate simply because it had obtained an interlocutory injunction requiring the defendant to retain similar shares to those that were the subject of the contract. The plaintiff argued that it would be unreasonable to be required to mitigate by entering the market to buy similar shares to those which were already the subject of the injunction. The plaintiff's argument was premised on the basis that it would be unreasonable to require it to expend additional money to mitigate when it still ostensibly held an interest in the shares wrongfully retained by the defendant. Justice Estey rejected this argument on the basis that there was no evidence of the plaintiff lacking the financial resources to mitigate. However, for our purposes, the more important comment is the one Justice Estey makes regarding a sale of shares:

It follows that a contrary result should arise where damages are recoverable for a breach of contract by a vendor on a sale of shares. There the breach would normally allow a buyer the use of his funds formerly committed to the purchase, and consequently damages should be calculated on the basis that he ought to have taken steps to avoid his losses by the purchase of shares on the market at the time of the breach. ${ }^{29}$

By analogy to the facts in Southcott, upon breach, the purchaser has freed up the funds it had committed to the purchase of the vendor's property. The law must operate on the assumption that the purchaser could have completed the sale, unless the purchaser wishes to risk being held in breach. This assumption is even more safely drawn where the purchaser is seeking specific performance and must itself be ready, willing, and able to complete the deal. It would be harsh law for a vendor to have already assumed a risk about the solvency of an impecunious purchaser, only to be confronted with the spectre of increased damages 
for its own breach because the purchaser lacks the financial resources to mitigate. A claim that impecuniosity changes the nature of what can reasonably be undertaken in mitigation has normally been applied to situations where the injury is a result of a tort or some other wrongdoing and where the plaintiff is truly having to commit funds unexpectedly to repair or replace goods or services ${ }^{30}$ or in a breach of contract situation where there has been a significant increase in market price, again, calling upon new funds above those originally contemplated under the breached contract. ${ }^{31}$ In contract settings, where a plaintiff's impecuniosity increases the damages, the law has normally insisted that the plaintiff's impecuniosity must be within the reasonable contemplation test (that is, the remoteness rule under Hadleyv. Baxendale ${ }^{32}$ ) at the time of contracting. In Southcott, the plaintiff would have to prove that at the time of contracting the Board could contemplate that Southcott would not have the financial resources to complete the deal; surely, a difficult argument for a property development company to make. ${ }^{33}$ No evidence was offered that the market price had significantly increased above the contracted price because the recession had in fact depressed the property market. The original decision to make an offer of purchase had come from Ballantry who had received the offering memorandum from the Board's real estate brokers. ${ }^{34}$

There is also a degree of artificiality about Southcott's claim of lack of financial resources. Southcott was always going to be dependent upon Ballantry to complete the purchase; they depended upon Ballantry for the deposit of $\$ 344,000$. Had the deal been completed, it is clear that the remaining purchase price would have been forthcoming, and, from the evidence of Ballantry itself, it did not lack financial resources. The explanation for keeping Southcott without financial assets was provided in the evidence of its principal and co-owner of Ballantry: namely, because once Southcott was involved in litigation against the Board, it "was a bad move," and one his lawyers would not have advised. ${ }^{35}$ Those who have deliberately structured their financial affairs to minimize their exposure to potential liabilities $^{36}$ or who experience a credit frailty ${ }^{37}$ have not normally been able to assert their impecuniosity as a defence to a lack of mitigation.

\section{Mitigation}

The assessment of damages for breach of a sale of property starts with the application of the market price rule. ${ }^{38}$ The purchaser is entitled to the difference between contract price and the market price of the property at the date of breach. A similar position prevails when it is the purchaser who is in breach of contract. The market price rule incorporates the obligation of mitigation because it assumes that a reasonable act of mitigation is to re-enter the market to purchase like property. Application of the market price rule does not actually require the

Alcoa Minerals of Jamaica Inc v Broderick, [2002] 1 AC 371 PC (Eng); Lagden v O’Connor, [2003] UKHL 64, [2004] 1 AC 1067 HL (Eng). Wroth $v$ Tyler, [1974] 1 Ch 30 [Wroth].

(1854) 9 Exch 341, 156 ER 145. See also Freedhoff v Pomalift Industries Ltd, [1971] 2 OR 773 (CA); McLean v Canadian Vickers Ltd, [1971] 1 OR 207 (CA) [Canadian Vickers].

Hillspring Farms Ltd v Leland Walton \& Sons Ltd, 2007 NBCA 7, 312 NBR (2d) 109 at paras 27-29. Southcott Ont Sup Ct, supra note 3 at para 9.

Southcott Ont CA, supra note 5 at para 18.

Cia Financiera Soleada SA v Hamoor Tanker Corp Inc, The Borag, [1981] 1 WLR 274 CA (Eng).

Canadian Vickers, supra note 32; Jamie Cassels \& Elizabeth Adjin-Tettey, Remedies: The Law of Damages, 2d ed (Toronto: Irwin Law, 2008) at 373.

S Waddams, The Law of Damages (Toronto: Canada Law Book, 2012) at paras 1-1480, 1-1730. 
purchaser to have made a purchase, only that he will be treated as if this was a reasonable step to take in mitigation. By giving damages measured as a difference in price the purchaser is placed in the position he would have been in had the contract been completed to the extent that a substitutionary remedy can do so. The application of the market price rule is conditional on there being an available market in which the purchaser could have secured like property. Where the assessment moves away from determining market price at the date of breach toward some other date, and, ultimately to the date of judgment, it is because the purchaser has been unable to secure like property in the market. More often, the dispute centres on whether the defendant can establish that the plaintiff failed to mitigate his loss and the burden is carried by the defendant to show that a market for the property existed at an earlier point in time. Stephen Waddams has suggested that the choice of determining when to apply a date of market price should be linked to when it is appropriate to treat the plaintiff as having "crystallized" its losses. ${ }^{39}$ This adopts the language used by Justice Estey in Asamera $^{40}$ and indicates the point in time when it is appropriate to reasonably impose the risks of further market price changes on the plaintiff.

The argument for not applying the market price rule in the sale of real property is that, given the nature of real property, the market place cannot offer a substitute with attributes identical to those of the property subject to the contract. This fact, that each piece of land is unique, has traditionally justified specific performance as the presumptive remedy in real property contracts. In the UK, where this approach still operates, damages for breach of contract will be determined by application of the market price rule where the purchaser has accepted the breach of contract, or, where the purchaser rejects the breach and insists upon specific performance, and then when the court refuses to order specific performance and gives damages in lieu. The latter event is more often determined at the date of judgment. ${ }^{41}$

As discussed above, Canadian law post Semelhago now rejects the idea that every contract for real property is presumptively unique. A purchaser must prove uniqueness to such an extent that damages would prove to be an inadequate remedy. In Canada, this is done by the plaintiff offering proof of the subjective characteristics that make the property unique in the eyes of the plaintiff and that there are no comparable substitute properties readily available with these characteristics. ${ }^{42}$ Regrettably, Canadian courts have done little to explore the concept of uniqueness. There is predominately a focus upon particular physical attributes of the property or its location which make it desirable to the purchaser and for which there is considerable consumer surplus (that is, idiosyncratic value held only by the plaintiff toward the property and for which damages would be difficult to quantify and offer a poor substitute). Following the majority's decision in Southcott, a property developer or investor can rarely prove particular characteristics of a property for which damages will not be an adequate substitute. With respect to the issue of comparable properties, the majority required evidence that other suitable investment properties existed in the greater Toronto region

Ibid at para 1-780.

Supra note 6 at 674 .

These are the rules that flow from Wroth, supra note 31; Johnson v Agnew, [1980] AC 367 HL (Eng) [Johnson].

$42 \quad$ Berryman, supra note 15 at 353. The plaintiff can prove uniqueness by demonstrating either particular physical attributes of the property (i.e. location, design, etc.); commercial or transactional attributes (i.e. suitability for re-zoning, or conversion to avoid rent control legislation, etc.); and personal factors particular to the plaintiff (i.e. proximity of home to a family member, or place of business, etc.). 
between the date of the contract and the trial. Suitability was established by proving that there were 81 parcels of raw land available for development which had a value between $\$ 1$ million and \$27 million, ranging in size between 2.3 and 110.8 acres, and which could be developed into low to medium density residential lots in under a year. Of these properties, two in particular were identified as comparable: one of 2.7 acres for $\$ 3.3$ million, and the other of 2.3 acres for $\$ 6$ million. Both these properties had been purchased by other Ballantry companies. The actual contract was for 4.78 acres at a contract price of \$3.44 million and would have generated 48 building lots upon subdivision. In contrast, the Chief Justice required a far greater similarity between the contracted property and the ones offered as comparable, both in terms of their physical attributes and potential to offer similar financial returns following development.

The issue of the availability of specific performance cannot be divorced entirely from the obligation to mitigate. If specific performance is available, the obligation to mitigate is suspended because the innocent party is entitled to keep the contract alive and does not have to accept the defendant's breach. The obligation to mitigate is suspended but will reemerge whenever specific performance becomes impossible, or where the innocent party does later accept the defendant's breach. ${ }^{43}$ In all levels of courts in Southcott, apart from the decision of the Chief Justice, the plaintiff was held not to have a fair, real, and substantial justification for specific performance. This finding meant that the issue turned to damages assessment for breach and establishing the point of crystallization of loss.

The law relating to mitigation requires the plaintiff to make reasonable efforts to mitigate loss; the rule of avoidable losses. The justification for such a rule is one of fairness and partly the application of causation principles. ${ }^{44}$ The plaintiff is not required to take extraordinary efforts or serious business gambles to reduce his losses. The test is an objective one, but it is also cognizant of the realities and circumstances facing the claimant at the time of breach. ${ }^{45}$ The cardinal principle has been stated by Viscount Haldane in British Westinghouse Co. v. Underground Railway: the plaintiff is not "under any obligation to do anything otherwise than in the ordinary course of business." ${ }^{\$ 6}$

Applying these principles to a contract concerning real property, one returns to the notion that a purchaser is entitled to the difference in contract price and market price at the point of crystallization. Determining the market value of real property presents challenges. Usually, this is done by considering sales of comparable property in the vicinity with similar attributes as the contracted property. If the plaintiff sought the difference in market value at the date of trial and contract price, the defendant would likely argue a lack of mitigation and then would have to prove that a market existed at a prior point in time in which comparable properties were available for purchase.

Johnson, supra note 41, where the plaintiff lost the right to continue with specific performance after a third party mortgagee exercised a power of sale and thus prevented the innocent party from being able to convey the property to the defendant.

44 Waddams, supra note 38 at para 15-70; Cassels \& Adjin-Tettey, supra note 37 at 375. Southcott SCC, supra note 2 at para 25 highlighting the fairness approach; British Columbia v Canadian Forest Products Ltd, [2004] 2 SCR 74 at para 176 highlighting the causation approach.

$45 \quad$ See Waddams, ibid at para 15-140; Cassels \& Adjin-Tettey, ibid at 377, both citing Banco de Portugal $v$ Waterlow, [1932] AC $452 \mathrm{HL}$ (Eng) at 506.

$46 \quad$ [1912] AC $673 \mathrm{HL}$ (Eng) at 689 [British Westinghouse]. 
In Southcott, the purchaser did not choose to argue for damages directly related to the loss of a bargain; that is, those associated with changes in market valuation of the land, because, in fact, there was no change in land values between contract and trial date. ${ }^{47}$ Rather, the purchaser confined its claim to consequential losses, the expected profits on subsequent sale of the developed lots. Applying normal principles, these losses are recoverable if not too remote and within the reasonable contemplation of the parties at the time of contracting. ${ }^{48}$ Again, this head of damages is subject to the rules of mitigation. ${ }^{49}$ At this stage, whether specific performance is available or not has no bearing on the inquiry. The availability of specific performance would only operate to justify a change in the date of assessment. Everything turns on the reasonableness of the purchaser's actions following acceptance of the breach, which, under the principles of Semelhago, it was effectively obligated to do. To require a property development company to continue the pursuit of other profitable developments does not appear unreasonable or anything other than in the ordinary course of business, which is consistent with the idea that mitigation does not require the plaintiff to do anything other than in the ordinary course of business. Mitigation does not have to be perfect. The plaintiff is protected in that it must give credit to the defendant to reduce the damages that flow from successful mitigation but is still able to recover any shortfall. ${ }^{50}$ Analyzed this way, the majority's approach in Southcott seems perfectly acceptable. The defendant was able to prove, on a balance of probabilities, from the evidence of purchases made by other Ballantry companies, as well as the purchases of similar property developers over the relevant period, that other land development opportunities existed. Because the plaintiff did not in fact undertake any mitigation, this led the majority, as well as the Court of Appeal, to conclude that the comparable developments provided by the defendant would have achieved identical or greater profitability to that envisaged under the contract. The Chief Justice would have required the defendant to identify to a much higher degree of similarity that the comparable properties offered, including the ones purchased by other Ballantry companies, the same profitable outcome.

The arguments of the majority are preferable. They are more consistent with the give and take concept of fairness that underlies mitigation. Just as the plaintiff cannot use a lack of financial resources, it should not be able to argue that it cannot secure an identical contractual performance to avoid a duty of mitigation. The plaintiff is always protected by a residual damages claim for any deficiency between what has been obtained in mitigation and that which was contracted, nor does mitigation require the plaintiff to have actually made the purchase of an alternative property. However, in law it will be treated as if it had done so.

\section{The Rule of Avoided Losses}

As has been discussed above, Southcott's claim for consequential losses required it to negate any claim that it had failed to mitigate its losses. Part of Southcott's argument was that there were no comparable properties that would have given the same return as that under the original contract. Another part of their argument was that purchases of development lands

Southcott Ont Sup Ct, supra note 3 at para 147.

Waddams, supra note 38 at para 1-1310; Cassels \& Adjin-Tettey, supra note 37 at 34, 71.

Waddams, ibid at para 1-1300.

Ibid at para 15-290. 
made by other Ballantry companies could not be viewed as missed opportunities by Southcott to mitigate because Ballantry did not lack resources to purchase any available development land that came to the market. This is the argument that development opportunities taken by other Ballantry companies were "collateral" to the claim made by Southcott because these opportunities did not arise out of the consequences of the breach and were independent of the failed contract with the school board.

This was an ingenious argument and, if accepted, was perfectly consistent and capable of explaining why Southcott did not make any active attempt to mitigate its loss. The argument was rejected in the Court of Appeal and by the majority in the Supreme Court of Canada, but on subsidiary grounds, rather than confronting the argument head on. Recall that the plaintiff earlier argued that it was a single purpose company, and thus its legal identity as distinct from Ballantry was an essential fact to explain why it had not mitigated its loss. Obviously, to now seek to take advantage of its linkage with Ballantry raised an inconsistency. As Justice Sharpe, speaking for the Court of Appeal, noted:

Southcott and Ballantry were certainly entitled to claim the legal benefit of limited liability by virtue of Southcott's distinct legal personality. However, Southcott and Ballantry also have to live with the consequences of the fact that because Southcott has a distinct legal personality, it is able to assert a claim for damages and, as a party asserting that claim, it thus bears the ordinary duty of mitigating its loss. ${ }^{51}$

Similar sentiments were expressed by Justice Karakatsanis for the majority in the Supreme Court of Canada. ${ }^{52}$ Thus, the reasonableness of Southcott's actions in mitigation was to be determined by reviewing its action alone; the fact of other purchases by Ballantry companies only provided evidence of comparable properties that could have been acquired by Southcott in mitigation.

The law covering the rule of avoided losses is notoriously difficult to apply. As Lord Bridge opined in Hussain v. New Taplow Paper Mill:

Many eminent common law judges, I think it is fair to say, have been baffled by the problem of how to articulate a single guiding rule to distinguish receipts by a plaintiff which are to be taken into account in mitigation of damage from those which are not. ${ }^{53}$

Simply put, the rule states that where the plaintiff has taken reasonable steps in mitigation in avoidance of the loss, the defendant should be credited by way of reduction in the damages that such mitigation has brought about. ${ }^{54}$ However, in application the rule requires one to parse the actions of the plaintiff and distinguish between those actions which flow as mitigation from those which the plaintiff could have taken in absence of the breach. The latter are characterized as being collateral, and the plaintiff does not have to bring gains made from those actions into account in reduction of the defendant's damages. The legal test to

Supra note 5 at para 27.

Supra note 2 at paras 30, 55.

[1988] 1 AC 514 at 528.

Waddams, supra note 38 at para 15-680 CA (Eng); H McGregor, McGregor on Damages, 17th ed (London: Sweet \& Maxwell, 2003) at para 7-089. 
make such a determination is that provided by Viscount Haldane in British Westinghouse: ${ }^{55}$ "[t]he subsequent transaction, if to be taken into account, must be one arising out of the consequences of the breach and in the ordinary course of business." The test has been endorsed by the Supreme Court of Canada. ${ }^{56}$

What actions, then, flow as a consequence of the breach? In the typical sale of goods setting, upon the seller's breach, the buyer has its assets freed up to obtain an alternative performance. Similarly, where it is the buyer's breach, the seller has the goods freed up for resale to another buyer. The application of the market price rule in damages assessment incorporates these actions. Where the buyer delays entering into the market and subsequently purchases at a lower price than the contract price, or where the seller retains the goods after breach and subsequently sells on a rising market, these gains and benefits have traditionally been viewed as collateral and not brought into account as mitigation. ${ }^{57}$ The rationale for this approach is that the innocent buyer or seller has reassumed the risk of the market place. Subsequent rises in the price of the goods for the buyer, or further falls in the market price for the seller, cannot be shifted to the defendant on the same rationale. ${ }^{58}$ The same result has been applied in a sale of land where specific performance was not in issue and where the purchaser had breached the contract. ${ }^{59}$ Two exceptions to this principle apply. One, is where there is no viable market to either purchase or sell the goods. The plaintiff, buyer or seller depending upon the case, may delay mitigation until a viable market exists. ${ }^{60}$

The second exception is that of the "volume seller." In this case, upon the buyer's breach, the seller resells the goods to a third party. The normal rule of mitigation would assume this subsequent sale as mitigating the seller's loss, and only if this sale was at a lower price, would the seller have incurred a loss. The volume seller displaces this argument by demonstrating that it can meet every buyer that comes along because it is not constrained by supply. Thus, the loss of any one sale is in fact a loss of profit on that particular sale and is therefore recoverable. ${ }^{61}$

This principle was applied to the lease of land by the Supreme Court of Canada in Apeco of Canada Ltd. v. Windmill Place. ${ }^{62}$ Windmill Place agreed to lease to Apeco premises $(2,526$ square feet) which were part of a warehouse and shopping mall (70,000 square feet) it owned. Apeco never took possession and repudiated the lease. At the time of entering into

Supra note 46 at 690.

$56 \quad$ Karas $v$ Rowlett, [1944] SCR 1 at 18; Apeco of Canada Ltd v Windmill Place, [1978] 2 SCR 385 at 389 [Apeco].

57 Campbell Mostyn v Barnett, [1954] 1 Ll Rep 65 CA (Eng) [Campbell Mostyn]; Jones v Just (1868), LR 3 QB 197 (ENG); Jamal v Moolla Dawood, Sons \& Co, [1916] 1 AC 175 PC (Eng) .

McGregor, supra note 54 at para 7-113.

Mavretic v Bowman (1993), 23 BCAC 298.

This argument was pursued in Campbell Mostyn, supra note 57. The buyer had rejected the delivery of 350 cans of ham that it had purchased from the seller. Rather than selling the hams that it had at the time of the breach, the seller held on to the cans and subsequently sold them at a price above the contract price. In a suit for the difference in contract price and market price at breach, the buyer argued that there was no market at the time of breach for the cans, and thus, the subsequent sale should be brought into account as an act of mitigation. The Court of Appeal rejected the buyer's argument largely on the evidence of the buyer's own witnesses who testified that there was a market, albeit a depressed one. Thompson (WL) Ltd v Robinson (Gunmakers) Ltd, [1955] 1 Ch 177 (Eng). Interestingly, on similar facts the reverse was held in Charter $v$ Sullivan, [1957] 2 QB 117 CA (Eng), but where the Court found that the demand for cars exceeded the supply. McGregor, supra note 54 at para 7-038; Waddams, supra note 38 at paras 5-1380, 15-750.

$62 \quad$ Apeco, supra note 56. 
the lease, Windmill's premises were entirely vacant. Soon after Apeco's breach, Windmill leased 17,000 square feet to another tenant, Goodboys. When Windmill sued Apeco for the loss on its lease, Apeco argued that the subsequent lease to Goodboys ought to be treated as an act of mitigation. This was rejected by the Supreme Court of Canada, which accepted the appellate court's conclusion that, because there was always surplus lease space available to meet any new tenant that approached Windmill, the lease to Goodboys was treated as an independent transaction. However, different consideration would apply if Windmill's premises had been fully leased. The decision is correct and makes good commercial sense where the underlying condition exists, namely, that the seller or landlord has excess market supply or capacity to meet every immediate demand. ${ }^{63}$

In Southcott the plaintiff, now viewed as being part of the Ballantry companies, argued that it should be treated as a "volume buyer," that it could buy every comparable development opportunity that came to the market such that any subsequent profit made from its other developments should not be treated as acquired from an act of mitigation. Were this argument accepted, it would have been the first time a "volume buyer," as against a "volume seller," would have enjoyed success. ${ }^{64}$

A number of observations can be made on this claim. First, it is only arguable where the plaintiff's claim is for consequential losses. As discussed earlier, the normal purchaser's claim involves a simple application of a market price rule either at the time of breach or, where specific performance is claimed, when it is abandoned in lieu of taking damages. Often the difference in market price will also reflect the development potential of the land. If consequential damages are included for lost profits, it is the difference in profits which could have been made on the land which is the subject of the disputed contract and the actual profits made from the land which has, or could have, been acquired as an act of mitigation. Even in this circumstance, the consequential losses may be discounted where other issues may have impacted upon the ability to actually proceed with the development. ${ }^{65}$ Furthermore, for the claim to be viable it requires evidential support that, indeed, the plaintiff has the financial capacity to buy every comparable property in order to demonstrate that its demand exceeds supply.

In Southcott, the evidence of Ballantry's financial capacity was described by the trial judge as being "far from complete or convincing," assertion that it had the financial capacity to make the purchases. It appears that the defendant did not challenge this finding, nor would it think that it had to on the state of the law existing prior to this case, there being no precedent for a "volume buyer." Even at an impressionistic level, it seems a rather incredible claim to make that, in a city the size of

$63 \quad$ For an example where a shopping mall that has been near fully leased, and thus must bring a subsequent new lease into account as mitigation see First Avenue Market Place (1986) Inc v Manthos (1995), 52 BCAC 232.

64 Waddams, supra note 38, makes no reference to the volume buyer, nor does McGregor, supra note 54, or Cassels \& Adjin-Tettey, supra note 37. The volume seller concept has been applied to the provision of services by a plaintiff where the plaintiff can prove that it would have been able to simultaneously undertake both the contract for service now breached, as well as the one the defendant is claiming should be treated as an act of mitigation. See Schluessel v Maier, 2001 BCSC 60, 85 BCLR (3d) 239, aff'd 2003 BCCA 405, 15 BCLR (4th) 209.

$65 \quad$ Eastwalsh Homes Ltd v Anatal Developments Ltd (1993), 12 OR (3d) 675 (CA).

$66 \quad$ Southcott Ont Sup Ct, supra note 3 at para 143. 
Toronto, a single property development company has the financial capacity to undertake every development comparable to the one in dispute. In addition, it is not only an issue of financial capacity to undertake every potential opportunity that may have arisen, but it also requires an institutional capacity to supervise and manage a large number of property developments simultaneously. Again, no evidence was provided that Ballantry had the resources, that is, planning, legal, contract management, and so on, to carry a large number of developments to fruition simultaneously.

There is at least one recent case which has flirted with the argument concerning a property developer as a "volume buyer" and the impact on mitigation and damages assessment. In $B$ $\&$ R Development Corp. v. Trail South Developments Inc. ${ }^{67}$ a property developer entered into an agreement to purchase a 3.5 acre parcel of undeveloped land zoned commercial for the purpose of a residential development. As in Southcott, the contract was conditional and in fact imposed mutual conditions on both purchaser and vendor to secure various planning and other municipal consents. The main dispute was whether the vendor had breached its obligations in failing to obtain these consents. At trial the vendor was found not to be in breach of contract, a finding upheld on appeal. However, the trial judge also dealt with the damages assessment argument. Similar to Southcott, the real purchaser, Bruno Mastroprimiano, intended to use a numbered company to purchase the property, and then create another company to do the actual development. Both companies would be held by the purchaser's holding company, B \& R Developments, which would advance funds to undertake the purchase and development. When the disputed contract failed to materialize, Mastroprimiano in fact turned his attention to another development. The trial judge held that no profits were actually lost and, thus, no damages would have been recoverable. ${ }^{68}$ If, indeed, the numbered company was simply a vehicle to acquire the property but not to undertake the actual development, then profits from the development could not be recovered because they would not have been incurred. Alternatively, if the transaction was viewed as really that of B \& R Developments, then the fact that another development was commenced subsequent to the collapse of the disputed contract be treated as an act of mitigation and would be taken into account in assessing damages.

On appeal, B \& R Developments argued that the subsequent development was of a different magnitude and not comparable to the development lost under the disputed contract. The Court of Appeal rejected this argument, noting that in Mastroprimiano's own evidence, he acknowledged that he had never done two developments of this size contemporaneously. ${ }^{69}$ Also significant is the fact that the subsequent development was of a different type, but was still treated as comparable for the purposes of determining mitigation. As the trial judge indicated:

I recognize that the nature of One River Park is substantially different [than] the proposed Trail South development. However, in a profit-oriented business mitigation is effected by producing profit. ${ }^{70}$

2012 ABCA 351, 539 AR 157, leave to appeal to SCC refused, 35192 (27 June 2013).

2011 ABQB 470, 508 AR 208.

Supra note 67 at para 72.

Supra note 68 at para 252. 
This approach to the facts is consistent with the majority's approach in Southcott to mitigation in the context of real property. For the property developer, comparability has more to do with the actual availability of other profitable developments than with identifying closeness in physical attributes of the properties.

Care must be taken in advancing arguments concerning "volume buyers.” The argument runs counter to the obligation to mitigate and the pragmatic application of the market price rule. If it is to be accepted, then the applicant should carry a high evidential burden to establish that it in fact does have access to all forms of resources, both capital and institutional capacity, to undertake what it is now asserting it would have done if the contract had not been breached by the defendant. The infrequency of cases which involve a "volume seller" further suggests a cautionary approach.

\section{CONCLUSION}

The majority's decision in Southcott clarifies a number of areas of law. First, it confirms the direction of the availability of specific performance where a property developer is acting as purchaser, which was first ennunciated by Justice Sopinka in Semelhago. Second, it informs issues surrounding the use of single purpose companies to develop property and what impact that organizational structure has on the obligation to mitigate. Third, it addresses what is expected of a property developer in undertaking reasonable steps of mitigation. The property developer cannot avoid mitigation simply by claiming that a comparable property in terms of similar physical attributes does not exist. The property developer has to demonstrate that there is no available market to purchase property which may return a development profit if it is called upon to explain why it could not reasonably mitigate loss. Conversely, the defendant need only establish that a range of viable properties existed for property development and which could have been acquired with the resources freed up to the plaintiff upon the defendant's breach. Finally, caution is warranted when a property developer seeks to argue that any subsequent development should be ignored on the basis that, as a "volume buyer," subsequent development should not be treated as collateral. 